\title{
Chronic Hepatic Venous Ischemia Secondary to Venous Outflow Insufficiency Causes Chronic Rejection in Pediatric Liver Transplant Recipients
}

\author{
Magd A. Kotb ${ }^{1}$, Mohamed ELGharib², Hesham Abd ElKader ${ }^{3}$, Magda El-Monayeri ${ }^{4}$, \\ Ahmed El-Hennawy ${ }^{5}$, Sherif Kaddah ${ }^{6}$, Hend Abd El Baky ${ }^{1}$, Nazira A. Abdalla1, \\ Radwa A. Shamma ${ }^{1}$, Iman Ali Abdel Aziz ${ }^{*}$ \\ 1 Department of Pediatrics, Faculty of Medicine, Cairo University, Egypt; magdkotb@kasralainy.edu.eg, \\ hend.elhossainy@gmail.com,nzanezo@hotmail.com,radwa.shamma@hotmail.com \\ 2 Interventional Radiology Department, Faculty of Medicine, Ain Shams University, Egypt; \\ mohgharibo@hotmail.com \\ 3 Pediatric Surgery Department, Faculty of Medicine, Ain Shams University, Egypt; \\ heshamabdelkader@yahoo.com \\ 4 Pathology Department, Faculty of Medicine, Ain Shams University, Egypt; mmonayeri@yahoo.com \\ 5 Pathology Department, Faculty of Medicine, Cairo University, Egypt; elhennawy_ahmed@yahoo.com \\ 6 Pediatric Surgery Department, Faculty of Medicine, Cairo University, Egypt; skaddah@hotmail.com \\ * Correspondence: imanaly@gmail.com \\ Received: 3/12/2021; Accepted: 12/12/2021; Published online: 27/12/2021.
}

\begin{abstract}
:
Background: Venous ischemia in a closed compartment results in congestion, impeded blood supply, cell death and a cascade of events that involves immune system to remove cellular debris. Aim of the Work: To report our experience with chronic hepatic venous ischemia post liver transplant.

Methods: We describe 3 girls and 4 boys with chronic hepatic venous ischemia secondary to chronic hepatic venous outflow insufficiency (CHVOI) post-liver transplant as confirmed by magnetic resonance venography (MRV) and by interventional radiograms.

Results: The mean age at transplantation was 6.75 years. Following transplant, within $8.5 \pm 1.7$ months they presented with progressive jaundice, ascites and hepatosplenomegaly. Imaging showed features consistent of CHVOI. The percutaneous liver biopsy revealed a picture of predominant chronic rejection and not of venous congestion. They improved clinically following hepatic venous dilation but not with change of type or dose of immuno-suppression. The venousoutflow tightness recurred with unsustained clinical improvement. Two children had stent placement. All others had irreversible progressive course developing end-stage liver disease. All were indicated for re-transplant. Of them 5 died awaiting re-transplant.

Conclusions: Chronic rejection among our studied children was due to insufficient intraoperative hepatic venous-outflow structural construction. CHVOI in children leads to graft loss and presents as chronic rejection. CHVOI should be ruled out in any child presenting with chronic rejection. Very generous hepatic venous outflow surgical construction technique should be planned, individualized and secured during liver transplant procedure. Stent placement is life-saving. Changes of immunosuppression medications is ineffective
\end{abstract}

Level of Evidence of Study: IIB (1).

Keywords: Chronic hepatic venous outflow insufficiency (CHVOI); chronic liver allograft rejection; hepatic venous outflow surgical reconstruction; pediatric liver transplantation. Abbreviations: CHVOI: Chronic hepatic venous outflow insufficiency; HVOA: hepatic venous outflow anastomosis; IVC: inferior vena cava; MRV: magnetic resonance venography.

\section{Introduction}

Chronic venous ischemia in a closed compartment results in congestion, arterial blood supply impediment and consequent cellular death $(2,3)$. Ulcer formation and cellular debris removal 
via immune system is a consequence (4). Hepatic venous outflow obstruction is a surgical complication of liver transplantation, that is known to present as an acute obstructive venous outflow with development of congestive hepatopathy, and graft loss unless timely managed (5). Chronic hepatic venous outflow insufficiency (CHVOI) following liver transplantation was never reported in children recipients of liver transplant grafts. CHVOI has been reported in children with veno-occlusive disease, those with Budd Chiari syndrome and restrictive cardiomyopathy and right sided heart failure (6). Ductopenia, chronic hepatocyte loss and progressive fibrosis over time are the whole-mark of chronic venous outflow insufficiency, irrespective of etiology and are also the same features of chronic liver transplant rejection $(7,8)$.

Operative hepatic venous reconstruction during liver transplant, done in children who are recipients of liver grafts, is expected to meet current flow, and to meet future remodeling. Future remodeling is a need to accommodate flow required by the growth in size of the children as they attain their adult height, weight and size $(9,10)$. We made the diagnosis of CHVOI in 7 children recipients of living related liver transplant, based upon the findings on magnetic resonance venography (MRV) and interventional radiogram of hepatic vessels. All underwent graft biopsy that showed features of chronic liver transplant rejection as interpreted by highly experienced pathologists. They improved timely upon interventional dilation, but the improvement was not sustained as the tightness recurred. Despite the lack of complete obstruction of venous outflow, we propose that the CHVOI causes slow steady engorgement of liver graft that initiates a sequence of chain reactions involving immune system ending in subclinical venous ischemia chronic, obliterative arteriopathy and bile duct loss. We aim to describe our experience with CHVOI among children recipients of living related liver transplant.

\section{Participants}

In this retrospective observational cohort study we analyzed data of 7 children recipients of living related liver transplant who suffered from CHVOI. The study was approved by Higher Studies Research Committee of Faculty of Medicine, Cairo University.

\section{Methods}

Analysis was performed of all data of studied cohort, including indication for transplantation, procedures, diagnostic criteria for diagnosis of CHVOI and outcome.

\section{Statistical Analysis}

Results were tabulated and analyzed statistically using SPSS software program (SPSS Statistics for Windows, Version 17.0. Chicago: SPSS Inc).

\section{Results}

Our study included 7 children (3 girls and 4 boys) who received liver transplantation for familial hypercholesterolemia, primary familial intrahepatic cholestasis type 3, Crigler Najjar syndrome and end stage liver disease following biliary atresia. The mean age at transplantation was 6 years and 8 months. They all underwent same technique of hepatic vein anastomosis.

After the native liver was removed, a vascular clamp was applied over the three hepatic veins of the recipient, making sure as possible not to completely occlude the lumen of the inferior vena cava (IVC). The 3 hepatic veins were opened into a single orifice by dividing the septa between them, and a triangulated end-to-end continuous anastomosis between the left hepatic vein of the graft and the confluence of the three hepatic veins of the recipient was done using three separate ampoules of 5/0 polydioxanone (PDS) sutures taking care to fix the anastomosis at three points to avoid rotation of the graft over the axis of the IVC and venous occlusion.

Within 8.5 1.7 months from transplantation, they all presented with jaundice then developed ascites and hepatosplenomegaly. Imaging revealed insufficiency of hepatic venous outflow. Percutaneous liver biopsy consistently revealed a picture of chronic rejection (Figures 1,2 and 3). One child had stent placement in surgically fashioned hepatic venous outflow. All others underwent initial improvement after interventional dilation, but it was not sustained. Six had irreversible progressive course and developed end stage liver disease. All 6 were indicated 
for re-transplant. Of them 5 died awaiting liver transplant. Tables 1, 2 describe the clinical presentation and outcomes of the studied cohort.

Table 1: Presentation and outcome of children recipients of liver transplant with chronic hepatic venous outflow insufficiency (CHVOI).

\begin{tabular}{|c|c|c|c|c|c|c|c|}
\hline & Child 1 & Child 2 & Child 3 & Child 4 & Child 5 & Child 6 & Child 7 \\
\hline Gender & Boy & Boy & Girl & Girl & Boy & Boy & Girl \\
\hline $\begin{array}{l}\text { Age at } \\
\text { transplantation }\end{array}$ & 18 months & $\begin{array}{l}9 \text { years, } \\
9 \text { months }\end{array}$ & $\begin{array}{l}\text { 3years, } \\
\text { 9months }\end{array}$ & $\begin{array}{l}5 \text { years, } \\
6 \text { months }\end{array}$ & $\begin{array}{l}8 \text { years, } \\
2 \text { months }\end{array}$ & $\begin{array}{l}8 \text { years, } \\
3 \text { months }\end{array}$ & 13 months \\
\hline $\begin{array}{l}\text { Indication for } \\
\text { transplantation }\end{array}$ & $\begin{array}{l}\text { Biliary } \\
\text { Atresia }\end{array}$ & PFIC3 & $\begin{array}{l}\text { Biliary } \\
\text { Atresia }\end{array}$ & $\mathrm{FH}$ & PFIC3 & $\begin{array}{l}\text { Crigler } \\
\text { Najjar }\end{array}$ & $\begin{array}{l}\text { Biliary } \\
\text { atresia }\end{array}$ \\
\hline $\begin{array}{l}\text { Age at chronic } \\
\text { rejection }\end{array}$ & 26 months & $\begin{array}{l}10 \text { years } 4 \\
\text { months }\end{array}$ & $\begin{array}{l}\text { 4years } 7 \\
\text { months }\end{array}$ & $\begin{array}{l}\text { 6years } \\
\text { 3months }\end{array}$ & $\begin{array}{l}8 \text { years } 9 \\
\text { months }\end{array}$ & $\begin{array}{l}\text { 8years } 9 \\
\text { months }\end{array}$ & $\begin{array}{c}2 \text { years } 2 \\
\text { months }\end{array}$ \\
\hline $\begin{array}{l}\text { Early post- } \\
\text { operative } \\
\text { events }\end{array}$ & $\begin{array}{l}\text { - acute } \\
\text { rejection, } \\
\text { - Ascites } \\
\text { that } \\
\text { resolved } \\
\text { within } 2 \\
\text { month, } \\
\text { - Followed } \\
\text { by chronic } \\
\text { rejection } \\
\text { within } 8 \\
\text { months }\end{array}$ & $\begin{array}{l}\text { - acute } \\
\text { rejection, } \\
\text { - Massive } \\
\text { ascites and } \\
\text { cholestasis } \\
\text { responding } \\
\text { to pigtail } \\
\text { placement }\end{array}$ & $\begin{array}{l}\text { - Ascites } \\
\text { (resolved in } \\
2 \text { months) }\end{array}$ & $\begin{array}{l}\text { - Ascites } \\
\text { (resolved in } \\
2 \text { months) } \\
\text { - Acute } \\
\text { rejection } \\
\text { (after } 4 \\
\text { month) } \\
\text { - Poor } \\
\text { response to } \\
\text { immunosup } \\
\text { pressive } \\
\text { medications }\end{array}$ & $\begin{array}{l}\text {-Acute } \\
\text { rejection, } \\
\text { massive } \\
\text { ascites and } \\
\text { graft } \\
\text { function loss } \\
\text {-responded to } \\
\text { surgical graft } \\
\text { repositioning }\end{array}$ & $\begin{array}{l}\text {-Acute } \\
\text { rejection, } \\
\text { massive } \\
\text { ascites } \\
\text { (responded to } \\
\text { surgical graft } \\
\text { repositioning) } \\
\text { - Chronic } \\
\text { rejection (8 } \\
\text { months later) }\end{array}$ & $\begin{array}{l}\text { - acute } \\
\text { rejection } \\
\text { (6months } \\
\text { later) }\end{array}$ \\
\hline $\begin{array}{l}\text { Presentation of } \\
\text { chronic hepatic } \\
\text { venous outflow } \\
\text { insufficiency } \\
\text { and venous } \\
\text { ischemia }\end{array}$ & $\begin{array}{l}\text { Cholestasis } \\
\text { and chronic } \\
\text { rejection } \\
\text { not responsiv } \\
\text { to immune } \\
\text { suppression }\end{array}$ & $\begin{array}{l}\text { Ascites that } \\
\text { resolved } \\
\text { after } \\
\text { placement } \\
\text { of stent } \\
\text { placement } 8 \\
\text { months } \\
\text { post- } \\
\text { operative } \\
\text { and HSM }\end{array}$ & $\begin{array}{l}\text { Cholestasis, } \\
\text { chronic } \\
\text { rejection } \\
\text { that is not } \\
\text { responsive to } \\
\text { immune } \\
\text { suppression, } \\
\text { short } \\
\text { stature, } \\
\text { ascites, liver } \\
\text { cell failure }\end{array}$ & $\begin{array}{l}\text { Cholestasis, } \\
\text { chronic } \\
\text { rejection not } \\
\text { responsive to } \\
\text { immune } \\
\text { suppression, } \\
\text { hyperchol- } \\
\text { esterolemia, } \\
\text { ascites and } \\
\text { liver cell } \\
\text { failure }\end{array}$ & $\begin{array}{l}\text { Cholestasis, } \\
\text { chronic } \\
\text { rejection not } \\
\text { responsive to } \\
\text { immune } \\
\text { suppression, } \\
\text { ascites and } \\
\text { liver cell } \\
\text { failure }\end{array}$ & $\begin{array}{l}\text { Cholestasis, } \\
\text { chronic } \\
\text { rejection not } \\
\text { responsive to } \\
\text { immune } \\
\text { suppression, } \\
\text { ascites, liver } \\
\text { cell failure, } \\
\text { intestinal } \\
\text { obstruction, } \\
\text { septicemia } \\
\text { and death }\end{array}$ & $\begin{array}{l}\text { Cholestasis, } \\
\text { chronic } \\
\text { rejection not } \\
\text { responsive } \\
\text { to immune } \\
\text { suppression, } \\
\text { ascites and } \\
\text { liver cell } \\
\text { failure }\end{array}$ \\
\hline
\end{tabular}

\section{Biopsy Chronic} Rejection Banff score (11)

\section{$3 / 9$}

$4 / 9$

$3 / 9$

$4 / 9$

$4 / 9$

$3 / 9$

$4 / 9$

Non had dilated sinusoids, congestion of central veins or hemorrhages. All had ductopenia, degenerative changes in remaining bile ducts, cholestasis, moderate to severe fibrosis, zone 3 hepatocyte variable inflammation, inflammatory cells in portal tract and hepatic parenchyma, and endothelitis or perivenular fibrosis. Stigmata of venous outflow insufficiency was also noted: dilatation and congestion of some sinusoids and collagen fiber deposition in other sinusoids were also encountered. They all progressed to cirrhosis.

CHVOI: Chronic hepatic venous outflow insufficiency; FH: Familial hypercholesterolemia; HSM: hepatosplenomegaly; PFIC3: Progressive intrahepatic cholestasis type3.

Immediate post-operative findings were consistent. All children had lactic acidosis lasting 36-48 hours post-operatively. During this period, the children struggled with ascites. Abdominal drains collected ascitic volume more than urine output volume for same duration. All had difficulty to raise and maintain central venous pressure to around $5 \mathrm{~mm} \mathrm{Hg}$ despite a positive balance of fluid intake. Intraoperative Doppler did not show complete obstruction. They all had chest symptoms ranging from wheezes, effusions to frank adult respiratory distress syndrome during the immediate post-operative 12 hour duration. The chest symptoms improved and waned by surgical interventions and diuretics. After a honeymoon period of less than a year they all presented with symptoms of CHVOI. They all had biliary ischemic strictures as well. A girl and a boy had intestinal obstruction heralding the development of CHVOI. One was operated upon where adhesions were found around area of venous outflow reconstruction beside other areas while and the other died during preparation for surgical exploration for cause of intestinal obstruction. 


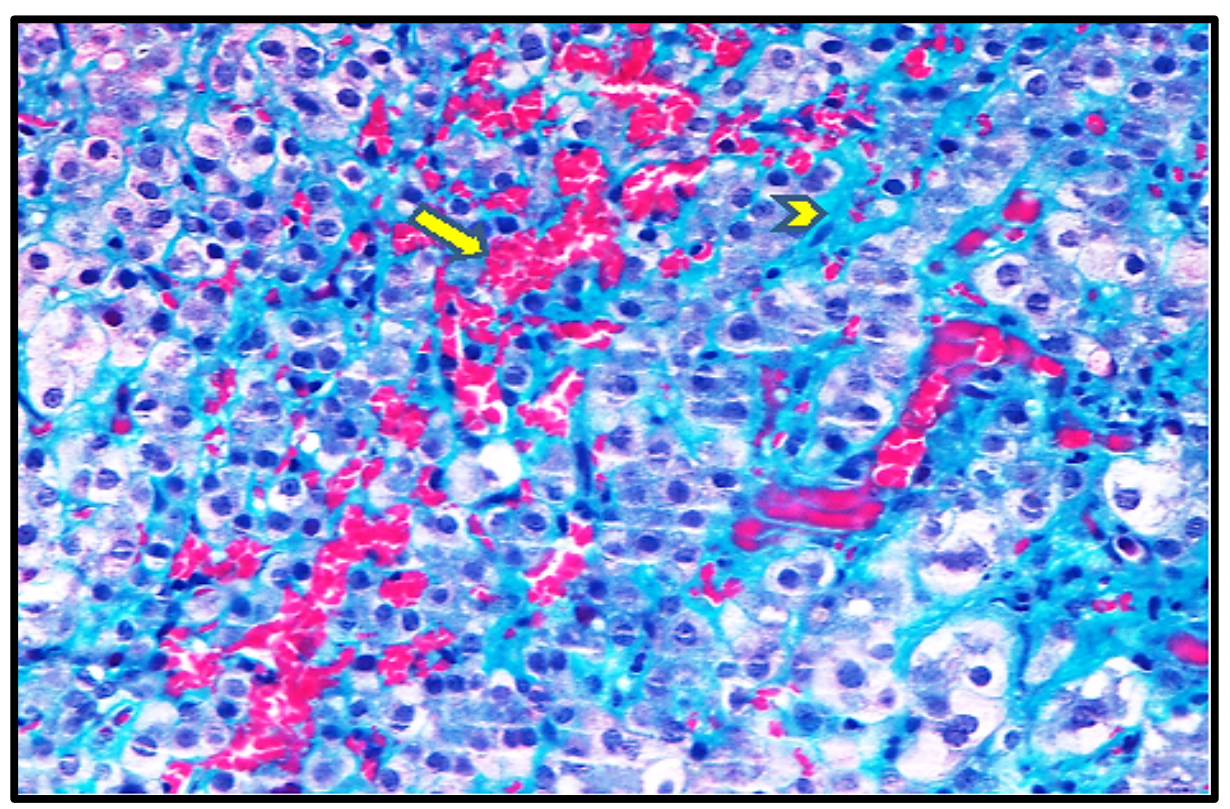

Figure 1: Liver allograft biopsy revealed evidence of chronic rejection of case 3. Stigmata of chronic venous outflow insufficiency are also present: dilatation and congestion of some sinusoids (arrow) and collagen fiber deposition in other sinusoids (arrow head) (Mallory trichrome, original magnification X400).

Table 2: Outcome of children recipients of liver transplant with chronic hepatic venous outflow insufficiency (CHVOI).

\begin{tabular}{|c|c|c|c|c|c|c|c|}
\hline & Child 1 & Child 2 & Child 3 & Child 4 & Child 5 & Child 6 & Child 7 \\
\hline Gender & Boy & Boy & Girl & Girl & Boy & Boy & Girl \\
\hline Intervention & & $\begin{array}{l}\text { Stent } \\
\text { placement } \\
\text { by } \\
\text { interventio } \\
\mathrm{n} \\
\text { radiography } \\
\text {. Stent was } \\
\text { occluded } \\
\text { and needed } \\
\text { balloon } \\
\text { dilatation }\end{array}$ & $\begin{array}{l}\text { Stent } \\
\text { placement } \\
\text { by } \\
\text { intervention } \\
\text { radiography }\end{array}$ & & $\begin{array}{l}\text { Anastomotic } \\
\text { dilation by } \\
\text { intervention } \\
\text { radiography }\end{array}$ & & Re-transplant \\
\hline $\begin{array}{l}\text { Imaging } \\
\text { diagnostic of } \\
\text { CHVOI }\end{array}$ & $\mathrm{MRV}$ & $\begin{array}{l}\text { Spiral CT, } \\
\text { MRV. } \\
\text { Venous } \\
\text { outflow } \\
\text { dilation } \\
\text { twice by } \\
\text { intervention- } \\
\text { al } \\
\text { radiograph, } \\
\text { followed by } \\
\text { failure of } \\
\text { dilation }\end{array}$ & MRV & MRV & $\begin{array}{l}\text { Spiral CT, } \\
\text { MRV. } \\
\text { Venous } \\
\text { outflow } \\
\text { dilation } \\
\text { twice by } \\
\text { intervention- } \\
\text { al } \\
\text { radiograph, } \\
\text { followed by } \\
\text { failure of } \\
\text { dilation }\end{array}$ & MRV & $\begin{array}{l}\text { - Imaging } \\
\text { studies were } \\
\text { negative for } \\
\text { CHVOI } \\
\text {-Operative } \\
\text { finding of } \\
\text { incomplete } \\
\text { axial torsion of } \\
\text { constructed } \\
\text { HV of first } \\
\text { transplant }\end{array}$ \\
\hline Outcome & $\begin{array}{l}\text { Died } \\
\text { within } \\
\text { 9months } \\
\text { of } \\
\text { diagnosis }\end{array}$ & $\begin{array}{l}\text { Portal } \\
\text { hypertension } \\
\text {-HSM \& } \\
\text { mild ascites }\end{array}$ & $\begin{array}{l}\text { Poorly } \\
\text { controlled } \\
\text { cholestasis, } \\
\text { liver cell } \\
\text { failure } \\
\text { awaiting re- } \\
\text { transplant }\end{array}$ & $\begin{array}{l}\text { Died within } \\
\text { 9months of } \\
\text { diagnosis }\end{array}$ & $\begin{array}{l}\text { Poorly } \\
\text { controlled } \\
\text { cholestasis, } \\
\text { liver cell } \\
\text { failure } \\
\text { awaiting re- } \\
\text { transplant }\end{array}$ & $\begin{array}{l}\text { Died within } \\
\text { 12months of } \\
\text { diagnosis }\end{array}$ & $\begin{array}{l}\text { Died } 3 \text { days } \\
\text { following re- } \\
\text { transplant }\end{array}$ \\
\hline
\end{tabular}

CHVOI: Chronic hepatic venous outflow insufficiency; HV: hepatic veins; HSM: hepatosplenomegaly; MRV: magnetic resonance venography. 


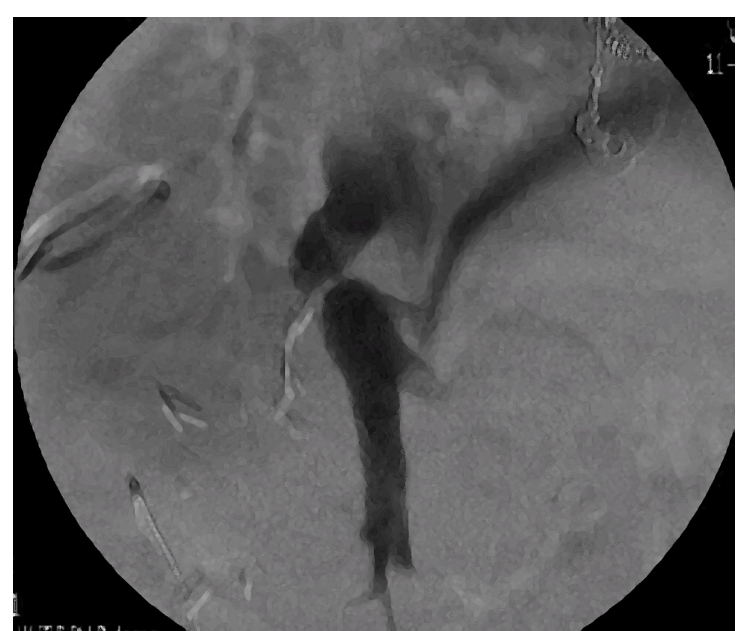

A

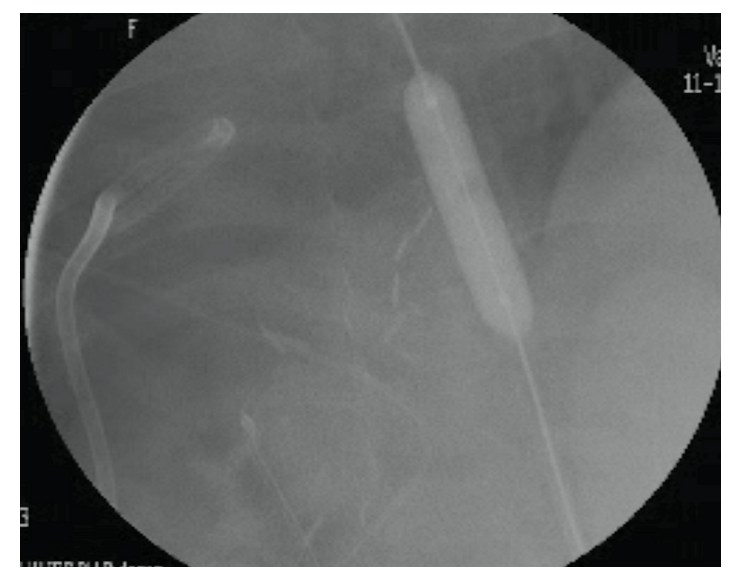

$\mathrm{C}$

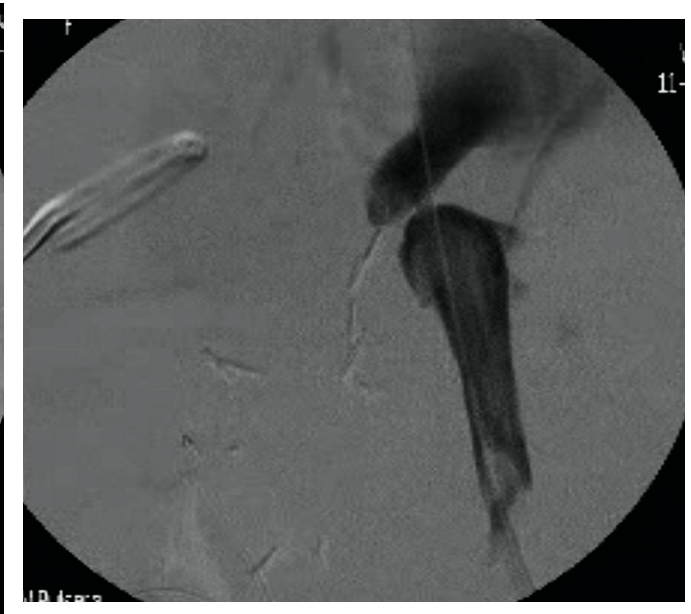

B

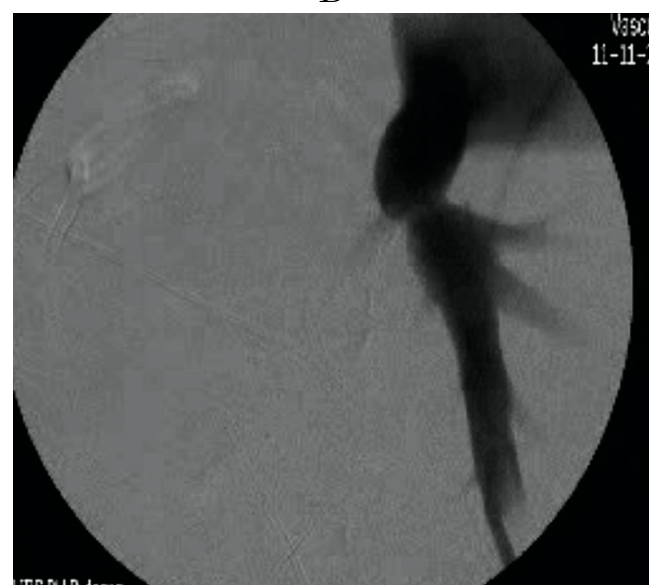

$\mathrm{D}$

Figure 2: Post liver transplant one year earlier with cholestasis, hepatomegaly, biopsy suggests chronic rejection and clinical suspicion of chronic venous outflow insufficiency. (A) Transhepatic venography showed tight stenosis between left hepatic vein and IVC, (B) After passing a guidewire and dilatation using a $6 \mathrm{~mm} \times 4 \mathrm{~cm}$ balloon with loss of balloon waist, (C) Final venography, (D) Loss of stricture with drop of pressure gradient less than $3 \mathrm{~mm} \mathrm{Hg}$, finally coil embolization.

\section{Discussion}

Not all Chronic Rejection is a Primary Immune Response Due to Innate Developmental factors. Recipient histocompatibility genes and resultant antigens are incriminated as potential causes of chronic rejection that has poor prognosis and is not amenable to therapy. The major histocompatibility complex is a human leukocyte antigen system is being currently considered the most aggressive contributor to allograft rejection (12). While primary immune response dictated by human leukocyte antigen is undeniably a crucial factor in development of allograft rejection, yet secondary immune response due to venous congestion is a factor that has to be always in the back of the mind of the transplantation team as it is a preventable cause of rejection.

CHVOI is Incomplete Insidious Venous outflow Obstruction. The liver capsule comprises an invagination of the peritoneum and the Glisson capsule. Once chronic insufficiency of hepatic venous outflow commences the graft will undergo 3 phases: 1- the liver graft gets congested, enlarges and initially the graft oozes fluid through the stretched capsule, resulting in transudate within the peritoneal cavity. 2- As the transudate organizes on surface of capsule, fibrosis and thickening of the capsule does not allow further enlargement of the graft, or transudate. Honeymoon period sets in and the graft is slowly decompensated with gradual rise of pressure within the graft rises leading to hepatocyte necrosis and fibrosis. 3- Stage of decompensation sets in with development of cirrhosis, portal hypertension and ascites. (Figure 4). 


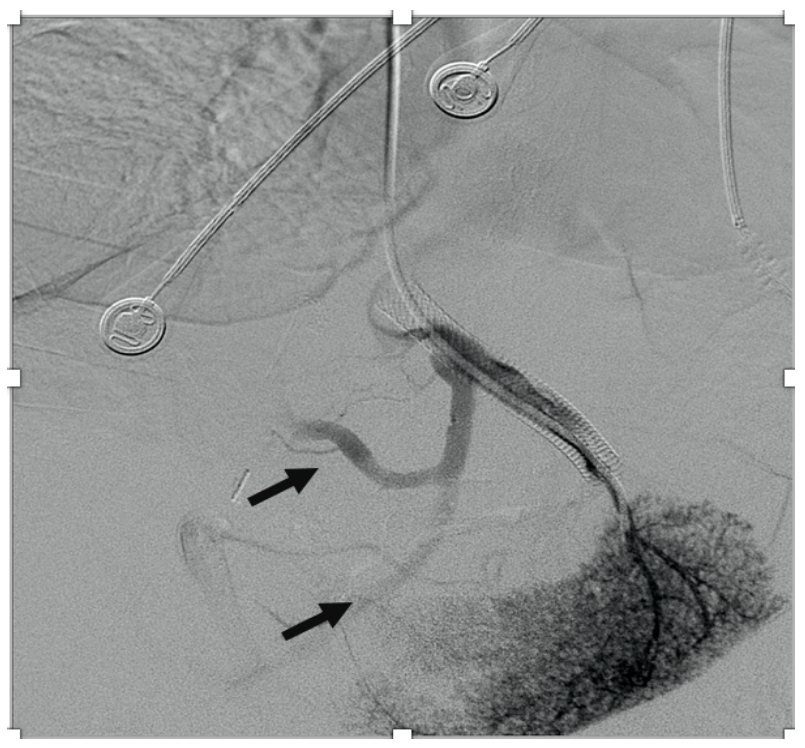

A

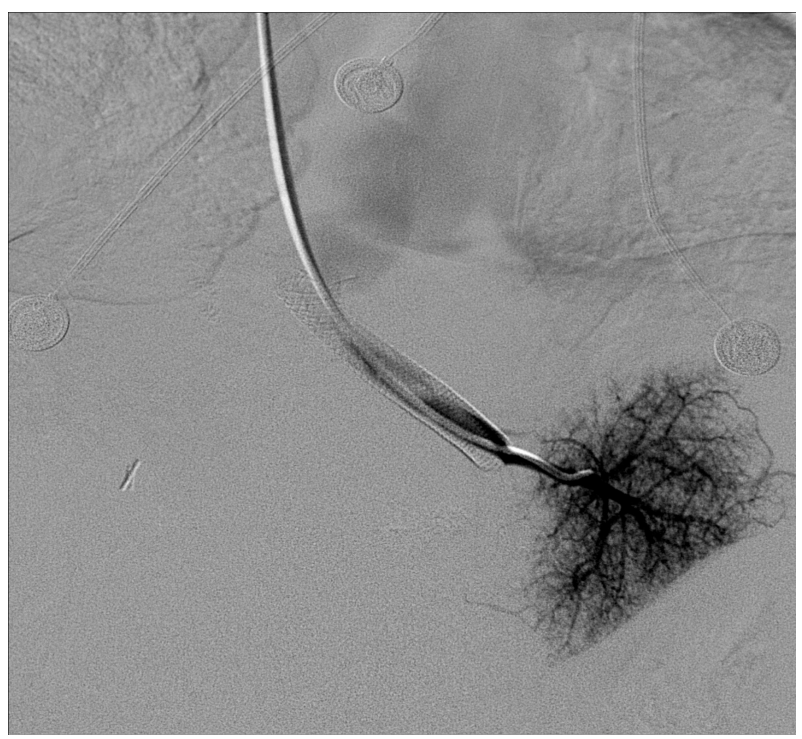

C

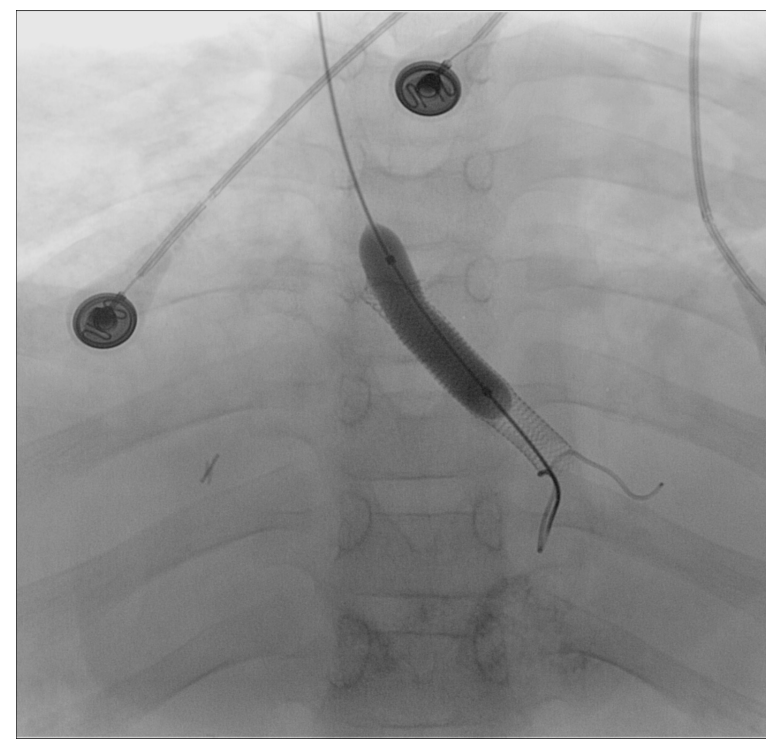

B

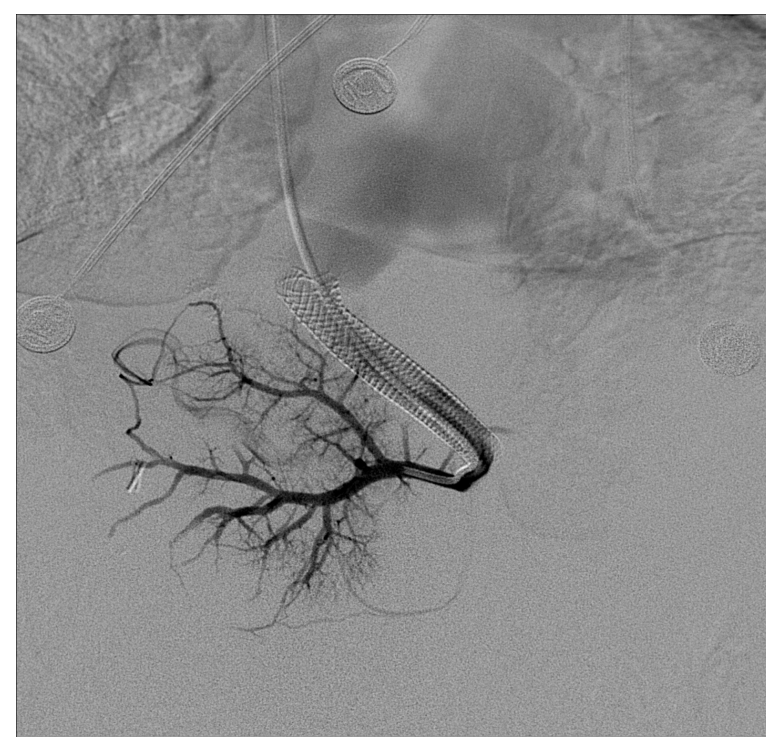

$\mathrm{D}$

Figure 3: Case 2: 10 year old male with history of liver transplant 2 years earlier, and left hepatic vein stent placement with symptoms of hepatic outflow insufficiency. (A) Venography with occluded stent and faint filling of the IVC. Note the presence of collaterals (arrows). (B) Balloon dilatation of the stent with $8 \mathrm{~mm}$ balloon. (C \& D) Final venography with filling of the IVC and disappearance of collaterals.

Post-operative accumulation of ascites volume more than amount of urine output, central venous pressure dropping despite maintained positive fluid balance, and development of chest symptoms (range from wheezes to full blown adult respiratory distress syndrome) is a triad that diagnoses CHVOI. The respiratory component is accentuated among those with more inadequacy of hepatic venous outflow anastomosis. The respiratory component results from decrement of venous return. The right side of heart pushes less blood to lungs, with drop of pressure in pulmonary vessels and rise of fluid in interstitium. Pulmonary complications range from mild pulmonary edema, adult respiratory distress syndrome till a full blown pulmonary hemorrhage. The magnitude of the respiratory component is reflected as low cardiac output symptoms, where kidneys struggle with hypo perfusion and ischemia. Absent respiratory component occurs in the subtle inadequacy of hepatic venous outflow. 

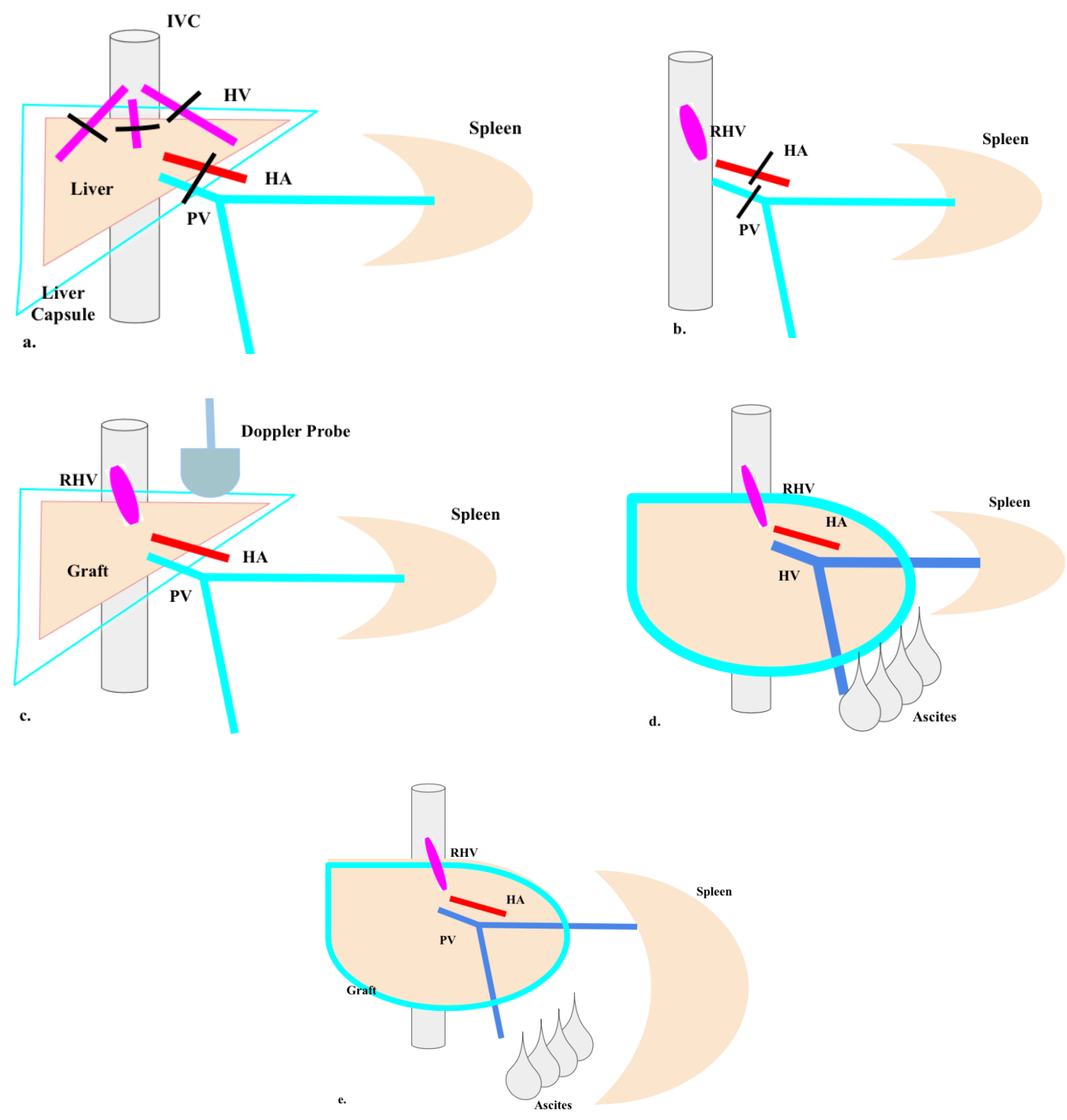

Figure 4: Pathogenesis of chronic hepatic venous outflow insufficiency (CHVOI) post-liver transplantation.

HA: hepatic artery, HV: hepatic veins, IVC: inferior vena cava, PV: portal vein, RHV: reconstructed hepatic vein surgically. a. Recipient hepatectomy. The native liver was removed a vascular clamp was applied over the three hepatic veins of the recipient, making sure as possible not to completely occlude the lumen of the IVC. b. Anhepatic phase almost 20-30 minutes. Hepatic vein anastomosis: The 3 hepatic veins are opened into a single orifice by dividing the septa between them, and a triangulated end-to-end continuous anastomosis between the left hepatic vein of the graft and the confluence of the three hepatic veins of the recipient is done using three separate ampoules of 5/0 PDS sutures taking care to fix the anastomosis at three points to avoid rotation of the graft over the axis of the IVC and venous occlusion. Anhepatic phase is associated with lactic acidosis, and peripheral pre-capillary sphincter release, and reduced venous return. c. The implantation of the graft and vascular anastomoses. Intraoperative doppler assesses the venous return in the reconstructed hepatic venous outflow. The volume flowing across the RHV is less than normal of child, as the venues return is reduced as outlined in (b). d. Graft gets engorged postoperatively as venous return volume increases after clearance of lactic acidosis. The increased pressure within the graft causes oozing of ascites of high protein content. d. The ascitic fluid protein content organizes on the surface of the capsule of the liver graft. Capsule becomes tough and pressure within graft increases, causing subtle venous ischemia, obliterative arteriopathy, bile duct loss, cholestasis pericentral, pericentral hepatocyte ballooning and dropout, progressive fibrosis, portal hypertension, splenomegaly and ascites.

CHVOI Leads to Insidious Venous Ischemia in the Compartmentalized transplanted Liver. The restricted outflow results in low-flow and hepatic congestion, with subsequent hepatocyte necrosis and ischemic ductopenia. 


\section{Misleading Factors that Mask the Prompt Diagnosis of CHVOI:}

1. Lactic acidosis associated with anhepatic phase does not allow proper intra-operative assessment of size of reconstructed hepatic venous outflow. Lactic acidosis is a serious complication of liver cell failure, and is augmented during the an-hepatic phase in liver transplantation (13). Stored blood transfusion increases the lactate load as well (14). Lactic acidosis releases pre-capillary sprinters, hence allowing more blood flow into capillaries and decrease venous return $(15,16)$. Hence the venous return to right side of heart after the an-hepatic phase is reduced. Accordingly the intra-operative Doppler imaging of hepatic venous outflow anastomosis (HVOA) sufficiency actually asses the adequacy of the HVOA in draining a fraction of the norm of venous return to right side of heart of the recipient. Within 48 hours the lactic acidosis is cleared and true venous return will have to exit the liver through the HVOA, hence all cases of CHVOI will develop insidiously. Yet, in substantial venous outflow inadequacy, if the volume of ascites exceeds that of urine, with struggling to maintain central venous pressure 5 or below, then CHVOI will present earlier.

2. Doppler is not $100 \%$ sensitive in the immediate post-operative phase for subtle insufficiency of venous outflow. Hepatic veins Doppler waveform normally is triphasic, as it reflects the transmitted cardiac cycle and atrial contraction. Yet, diphasic or monophonic waves are accepted as normal post-operatively (17). Not only is the venous return volume changing but also the inherent "normality of the not-triphasic wave" renders the Doppler imaging not the diagnostic modality for subtle insufficiency of HVOA.

3. Post-operative systemic effects of CHVOI on renal function might be delayed to notice. Urea is synthesized only in the liver (18), hence a comprised graft will not mount the necessary urea to allow diagnosis of hypo perfusion of kidneys in the event of frank inadequacy of HVOA.

4. Remodeling in children is a dynamic process during growth. All organs do not grow by external addition of tissue, but by remodeling, where organs and their blood supply are remodeled during the process of growth (19). This remodeling does apply uniformly to anastomotic sites. Hence, remodeling is not always effective in fixing an inadequate or less than generous HVOA. Moreover, effective remodeling is suppressed by the immunesuppression post-operatively. Hence, CHVOI due to subtle or frank inadequacy of HVOA is more likely to set in, as remodeling will not be able to overcome this inadequacy of HVOA.

5. Extra vascular compression by fibrous bands is a cause of CHVOI. Postoperative organization of fibrin with development of post-operative adhesions (20) is a potential cause of external compression of the HVOA. It is unpredictable, and is a diagnosis that should be ruled out in any child with post-transplant CHVOI.

6. Honeymoon period until development of full blown end stage CHVOI is variable. The honey moon period duration depends upon the extent of inadequacy and efficacy of remodeling.

7. Ischemic biliary strictures and cholestasis complicate all cases of CHVOI. All our cases had later onset biliary strictures, and not typically anastomotic biliary strictures. Late onset biliary strictures are typically ischemic strictures (21), which could be easily misdiagnosed as secondary to macro/micro-angiopathy associated with preservation injury, (prolonged cold and warm ischemia times, donation after cardiac death, and donor prolonged use of vasopressors) and immune mediated injury of chronic rejection. Hence the biliary strictures would be interpreted as chronic rejection $(22,23)$.

8. Liver graft biopsy findings in CHVOI are typical of chronic rejection and ductopenia. CHVOI results in slowly progressive build of pressure with the graft and obliterative of artriopathy. Acute venous ischemia is well known (11) but chronic venous outflow insufficiency is mostly diagnosed as chronic rejection associated with venous anastomotic strictures. The bile duct ischemic strictures develop on top of CHVOI as well.

9. Poor response to immune suppression is present in all CHVOI. Our cohort showed response to interventional venous dilation but not to change in immune suppression dose or type. The response was transient except for the boy who underwent venous outflow stent placement.

10. There is no typical histopathology of liver coined to CHVOI. Hence the diagnosis is confused with chronic rejection. The immune involvement in CHVOI is an essentially typical response to ischemia (7). 
Generous venous outflow reconstruction prevents CHVOI, venous ischemia and chronic rejection. It is regrettable that outcome of CHVOI is related to its early prompt recognition and stent placement, and not mere venous outflow dilation. The biopsy findings are confounding and delay the diagnosis, where treating physicians spend a lot of time attempting to provide suitable medical treatment, while it is surgical condition. The intra-operative Doppler imaging is not a suitable guide for adequacy of the reconstructed hepatic venous outflow.

Pre-operative planning of generous hepatic venous outflow is a must. It is not clear how much of the cases that are diagnosed as chronic rejection have a degree of CHVOI and venous ischemia. It is important to notice that terminal hepatic venules involvement is a feature of chronic rejection.(24) The reconstruction of hepatic venous outflow is a single most important factor to prevent CHVOI.

\section{Conclusion}

CHVOI in children leads to graft loss and presents as chronic rejection. CHVOI should be ruled out in any child presenting with chronic rejection. Stent placement is life-saving. Preemptive very generous hepatic venous outflow surgical reconstruction technique should be planned, individualized and secured during liver transplant. Not all rejection is a primary immune response. CHVOI is a preventable cause of graft loss.

\section{Acknowledgment}

The authors would like to acknowledge the efforts of late Professor Alaa F. Hamza, Late Professor of Pediatric Surgery and Former President of Ain Shams University, Egypt and Professor Ahmed Kotb, Late Professor of Pediatrics, Faculty of Medicine, Cairo University, Egypt.

\section{Author Contributions:}

All authors shared in conceptualization, supervising, data curation, data analysis, writing original draft, data interpretation, writing original draft, supervising and revising. All authors reviewed the final manuscript. All authors have read and agreed to the published version of the manuscript.

\section{FUNDING}

Authors declare there was no extramural funding provided for this study.

\section{CONFLICT OF INTEREST}

The authors declare no conflict of interest in connection with the study.

\section{References}

1. Sundaram V, Fang JC. Gastrointestinal and Liver Issues in Heart Failure. Circulation. 2016;133(17):1696-1703. doi:10.1161/CIRCULATIONAHA.115.020894

2. Reece K, Day R, Welch J. Superior Mesenteric Artery Syndrome with Abdominal Compartment Syndrome. Case Rep Emerg Med. 2016;2016:1-4. doi:10.1155/2016/7809281

3. Loots MA, Lamme EN, Zeegelaar J, Mekkes JR, Bos JD, Middelkoop E. Differences in cellular infiltrate and extracellular matrix of chronic diabetic and venous ulcers versus acute wounds. J Invest Dermatol. 1998;111(5):850-857. doi:10.1046/j.1523-1747.1998.00381.x

4. Wahab MA, Shehta A, Hamed H, et al. Hepatic venous outflow obstruction after living donor liver transplantation managed with ectopic placement of a foley catheter: A case report. Int J Surg Case Rep. 2015;10:65-68. doi:10.1016/j.ijscr.2015.03.017

5. Valla DC. Budd-Chiari syndrome/hepatic venous outflow tract obstruction. Hepatol Int. 2018;12(Suppl 1):168-180. doi:10.1007/s12072-017-9810-5

6. Tanaka M, Wanless IR. Pathology of the liver in Budd-Chiari syndrome: portal vein thrombosis and the histogenesis of veno-centric cirrhosis, veno-portal cirrhosis, and large regenerative nodules. Hepatol Baltim Md. 1998;27(2):488-496. doi:10.1002/hep.510270224 
7. Tian Y, Deng H, Han L, Hu S, Qi X. Hypoxia-inducible Factor may Induce the Development of Liver Fibrosis in Budd-Chiari Syndrome by Regulating CD248/endosialin Expression: A Hypothesis. J Transl Intern Med. 2018;6(2):66-69. doi:10.2478/jtim-2018-0018

8. Leutert G. [Morphological age changes of the heart and blood vessels--contribution to the asynchronous aging of human organs and tissues]. Z Gesamte Inn Med. 1976;31(4):98-104.

9. Majesky MW. Vascular Development. Arterioscler Thromb Vasc Biol. 2018;38(3):e17-e24. doi:10.1161/ATVBAHA.118.310223

10. Shi X, Han W, Ding J. The impact of human leukocyte antigen mismatching on graft survival and mortality in adult renal transplantation: A protocol for a systematic review and metaanalysis. Medicine (Baltimore). 2017;96(49):e8899. doi:10.1097/MD.0000000000008899

11. E S. Intraoperative Serum Lactate Concentration and Central Venous Oxygen Saturation as Early Predictors for Early Graft Function during Liver Transplant. J Anesth Intensive Care Med. 2018;5(1). doi:10.19080/JAICM.2018.05.555655

12. Schroeder TH, Hansen M. Effects of fresh versus old stored blood in the priming solution on whole blood lactate levels during paediatric cardiac surgery. Perfusion. 2005;20(1):17-19. doi:10.1191/0267659105pf784oa

13. Jacob M, Chappell D, Becker BF. Regulation of blood flow and volume exchange across the microcirculation. Crit Care Lond Engl. 2016;20(1):319. doi:10.1186/s13054-016-1485-0

14. Spadaro S, Reverberi R, Fogagnolo A, et al. Transfusion of stored red blood cells in critically ill trauma patients: a retrospective study. Eur Rev Med Pharmacol Sci. 2015;19(14):26892696.

15. Chong WK, Beland JC, Weeks SM. Sonographic evaluation of venous obstruction in liver transplants. AJR Am J Roentgenol. 2007;188(6):W515-521. doi:10.2214/AJR.06.1262

16. Barmore W, Azad F, Stone WL. Physiology, Urea Cycle. Treasure Island (FL): StatPearls Publishing https://www.ncbi.nlm.nih.gov/books/NBK513323/

17. Udan RS, Culver JC, Dickinson ME. Understanding vascular development. Wiley Interdiscip Rev Dev Biol. 2013;2(3):327-346. doi:10.1002/wdev.91

18. Blachar A, Federle MP. Bowel obstruction following liver transplantation: clinical and ct findings in 48 cases with emphasis on internal hernia. Radiology. 2001;218(2):384-388. doi:10.1148/radiology.218.2.r01ja22384

19. Ryu CH, Lee SK. Biliary strictures after liver transplantation. Gut Liver. 2011;5(2):133-142. doi:10.5009/gnl.2011.5.2.133

20. Tsujino T, Isayama H, Kogure H, Sato T, Nakai Y, Koike K. Endoscopic management of biliary strictures after living donor liver transplantation. Clin $J$ Gastroenterol. 2017;10(4):297-311. doi:10.1007/s12328-017-0754-z

21. Jeng LB, Thorat A, Yang HR, Li PC. Venous outflow reconstruction in living donor liver transplantation: Dealing with venous anomalies. World J Transplant. 2015;5(4):145-153. doi:10.5500/wjt.v5.i4.145

22. Demetris AJ, Bellamy C, Hübscher SG, et al. 2016 Comprehensive Update of the Banff Working Group on Liver Allograft Pathology: Introduction of Antibody-Mediated Rejection. Am J Transplant Off J Am Soc Transplant Am Soc Transpl Surg. 2016;16(10):2816-2835. doi:10.1111/ajt.13909

23. Ye Q, Zeng C, Wang Y, et al. Risk Factors for Hepatic Venous Outflow Obstruction in Piggyback Liver Transplantation: The Role of Recipient's Pattern of Hepatic Veins Drainage into the Inferior Vena Cava. Ann Transplant. 2017;22:303-308. doi:10.12659/aot.902753

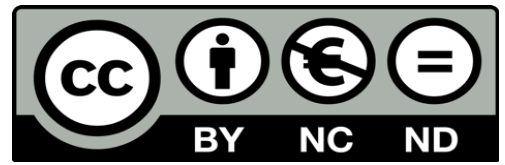

(c) 2021 submitted by the authors. Open access publication under the terms and conditions of the Creative Commons Attribution (CC- BYNC- ND) license. (https://creativecommons.org/licenses/by-nc-nd/2.0/). 